А. І. Дворецький /д. б. н./

В. І. Ляшенко /к. т. н./

Ф. Ф. Топольний /д. б. н./

Г. Д. Коваленко /Д. ф.-м. н./
ДВУЗ «Дніпровський державний аграрноекономічний університет», м. Дніпро, Україна e-mail: dvoretsk@list.ru

ДП «Український науково-дослідний та проектно-розвідувальний інститут промислової технології», м. Жовті Води, Україна e-mail: vilyashenko2017@gmail.com ДВУЗ «Центральноукраїнський національний технічний університет», м. Кропивницький, Україна e-mail: topolniy@gmail.com

НД3 «Український науково-дослідний інститут екологічних проблем», м. Харків, Україна e-mail: grygoryk0@gmail.com

\title{
Вплив уранової промисловості на стан довкілля та населення ${ }^{1}$
}

\author{
A. I. Dvorezkij /Dr. Sci. (Biolog.)/ \\ V. I. Lyashenko /Cand. Sci. (Tech.)/ \\ F. F. Topolnij /Dr. Sci. (Biolog.)/ \\ G. D. Kovalenko /Dr. Sci. (Tech.)/
}

GVUS "Dniprovsky state agrarian and economic university", Dnipro, Ukraine e-mail: dvoretsk@list.ru HP "Ukrainian scientific-research and designprospecting Institute of industrial technology:, Zheltye Vody, Ukraine e-mail: vilyashenko2017@gmail.com GVUS "Central Ukrainian National Technical University", Kropivnizkij, Ukraine e-mail: topolniy@gmail.com Scientific Research Institution "Ukrainian Research Institute of Environmental Problems", Kharkov, Ukraine e-mail: grygoryk0@gmail.com

\section{Influence of uranium industry on the state of environment and population}

\begin{abstract}
Мета. Дати оцінку впливу уранової промисловості на стан довкілля та населення на основі розробки та впровадження інженерно-технічних рішень та заходів щодо зменшення ү-випромінювання та концентрації радону в приміщеннях, виконання екологічної та соціально-побутової реабілітації забрудненої території, житлових будинків, об'єктів соціальної сфери та населення, що проживає в зоні впливу, для підвищення екологічної безпеки довкілля та населення, мінімізації негативного впливу радіаційних та інших факторів.

Методика. Використано радіометричні методи (вимірювання експозиційної дози та інтенсивності $\gamma$-випромінювання, вимірювання радіоактивності $\gamma$ - $і \beta$-випромінювання, вимірювання потужності експозиційної дози ү-випромінювання, визначення потужності поглиненої дози ү-випромінювання в повітрі, аналіз природних радіонуклідів (ПРН); статистичний та математичний методи дослідження з використанням комплексного системного підходу. Радіоекологічні дослідження включали: вимірювання потужності експозиційної дози (ПЭД) ү-випромінювання за мережею 100×100 м і 20×10 м (пішохідна ү-зйомка) в обсязі 40 км²; аналіз грунтів на вміст радіонуклідів; відбір проб води на вміст радію та урану; визначення сумарної $\alpha$ - $i$ $\beta$-активності грунтів; визначення концентрації радону в житлових приміщеннях.

Результати. Показано роль спеціалістів різних органів державної влади та місцевого самоврядування у вирішенні вищезгаданих завдань для регіонів, що знаходяться в зоні впливу гірничо-металургійних комбінатів з видобутку та первинної переробки уранових руд. Встановлено, що перевищення нормативного рівня
\end{abstract}

${ }^{1}$ Роботу виконано за сприяння спеціалістів провідних наукових інститутів та центрів України, громадськості регіонів, Кабінету Міністрів України та інших, розпочинаючи з 1995 р. 


\section{экология}

еквівалентної рівноважної концентрації радону 50 Бк/м³ в окремих приміщеннях, обумовлене його виділенням з простору під підлогою та каналів введення зовнішньої теплової та водопровідної мереж, внутрішніх каналів розподілу тепломереж.

Наукова новизна. Доводиться, що засипка каналу теплової мережі із зовнішнього боку будівлі шаром глини на глибину 1 м і його ущільнення, герметизація введення теплової та водопровідної мереж через фрундамент будівлі та бетонування приямка зменшують об'ємну активність радону в приміщенні в 5-6 разів.

Практична значущість. Наведений поки що рідкісний досвід щодо підвищення радіаційного та соціального захисту населення міста Жовті Води, яке проживає в зоні впливу об'єктів уранової промисловості. (Іл. 6. Бібліогр.: 27 назв.)

Ключові слова: радіоекологія, уранове виробництво, державні програми, природоохоронні заходи, радіаційний та соціальний захист населення.

Вступ. Характерною особливістю Придніпровського регіону України є розробка та первинна переробка уранових руд в м. Жовті Води. Наявність підприємств початкової стадії ядерного циклу в містах Жовті Води, Кам'янське (рис. 1), функціонування Запорізької АЕС, захоронення радіоактивних відходів, призвело до формування у регіоні складної радіоекологічної ситуації. Місто Жовті Води - єдине в Україні, де 3 50-х років XX ст., проводиться видобуток та первинна переробка уранової сировини - основи ядерного палива для атомної енергетики. На його території знаходиться Жовторічанське родовище залізоурано-скандієвих руд. Розробка цього родовища проводиться з 1895 р. Спочатку розробки і до се-

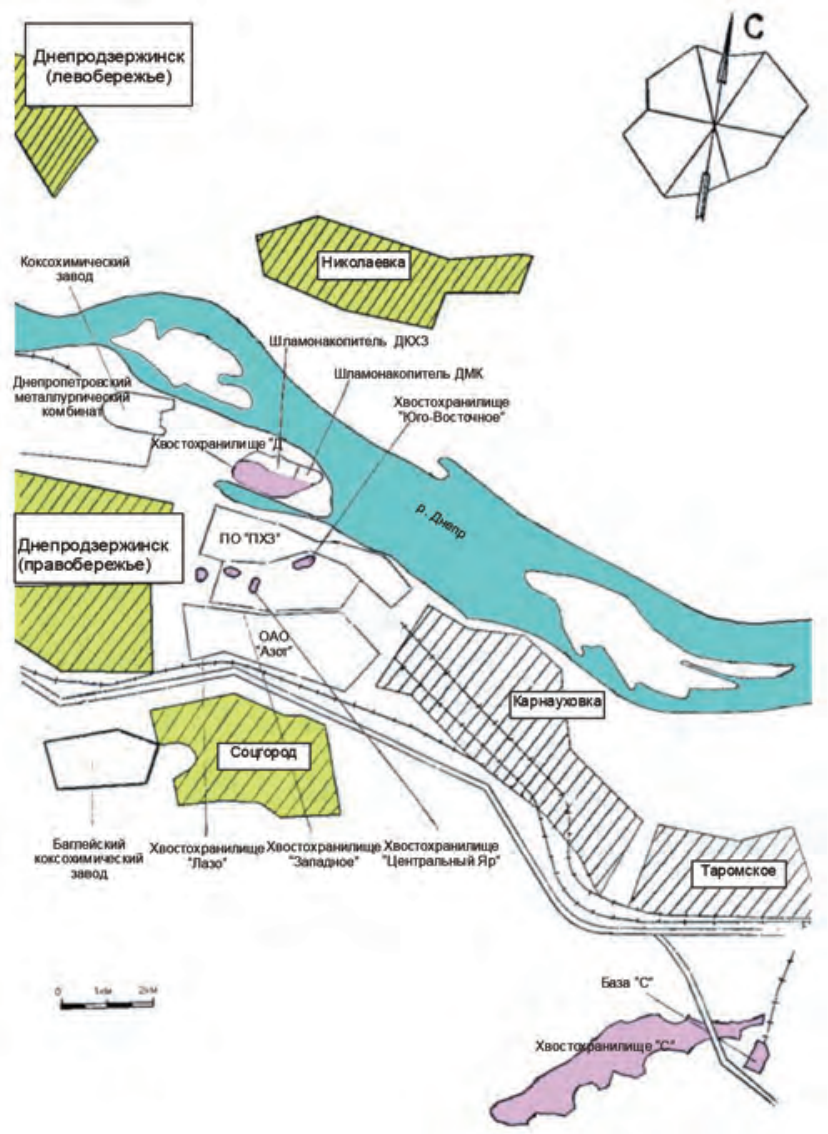

a) редини 40-х років минулого століття відбувався видобуток збагачених залізних руд, а з 1951 р. розпочалася розробка уранових руд, яка була завершена наприкінці 1989 р.[1-4]. На зазначених територіях розташовувалися основні уранові виробництва (шахти, рудники, промислові майданчики гірничо-металургійних комбінатів, гідрометалургійних заводів, хвостосховища тощо), які зазнали техногенного забруднення. Для таких територій актуальними завданнями є приведення ïx до екологічно безпечного стану. У той же час практичне вирішення цих завдань стримується через брак досвіду планування і реалізації проектів відновлення навколишнього середовища, відсутність фінансових ресурсів для здійснення

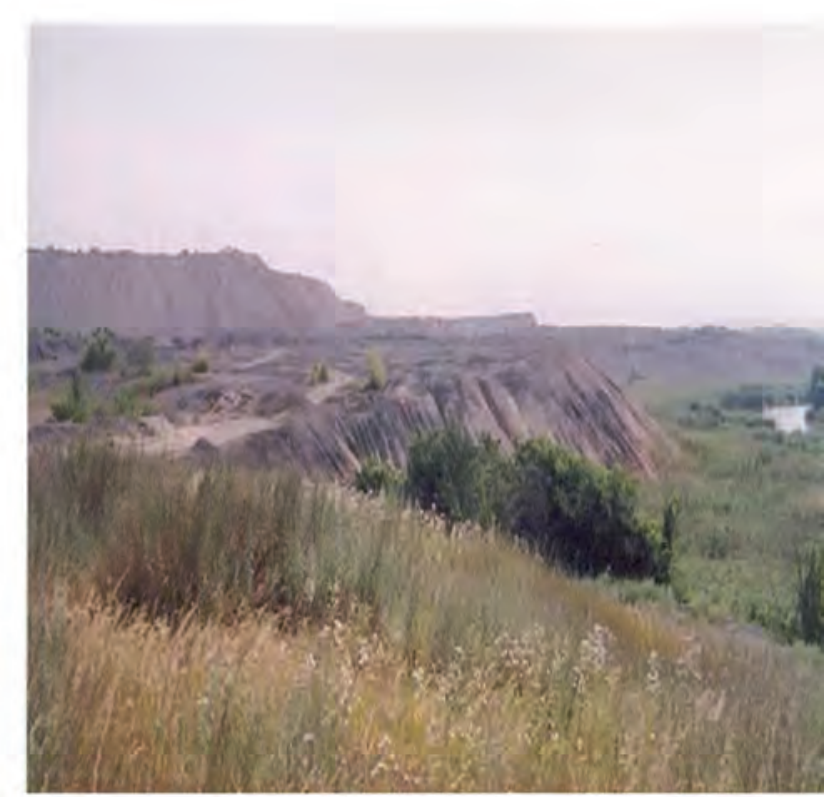

Рис. 1. Розміщення хвостосховищ на території колишнього ВО «ПХЗ»: а - схема: ДКХЗ - Дніпровський коксохімічний завод; ДМК - Дніпровський металургійний комбінат; «Д» - «Дніпровське»;

$$
\text { б - загальний вид хвостосховища «Дніпровське» }
$$


довготривалих реабілітаційних програм. Тому оцінка впливу уранової промисловості на стан довкілля та населення, розробка та впровадження інженерно-технічних рішень та заходів щодо зменшення ү-випромінювання та концентрації радону в приміщеннях, виконання екологічної та соціально-побутової реабілітації забрудненої території, житлових будинків, об'єктів соціальної сфери та населення, що проживає в зоні ії впливу, спрямованої на охорону навколишнього середовища та його захист, є важливим науковим, народногосподарським і соціальним завданням.

Методи дослідження і прийняті терміни. Автори використовували радіометоди (вимір експозиційної дози й інтенсивності ү-випромінювань, вимірювання радіоактивності $\gamma$ - і $\beta$-випромінювання, вимірювання потужності експозиційної дози ү-випромінювання, визначення потужності поглиненої дози ү-випромінювання в повітрі, аналіз ПРН); статистичний і математичний методи досліджень 3 використанням комплексного і системного підходів. Радіоекологічні дослідження включали: вимірювання потужності експозиційної дози (ПЕД) ү-випромінювання за мережею 100×100 м і 20×10 м (пішохідна ү-зйомка) в обсязі 40 км²; аналіз грунту на вміст радіонуклідів; відбір проб води на вміст радію і урану; визначення сумарної а- i $\beta$-активності грунту; визначення концентрації радону в житлових приміщеннях [5-7].

Радіаційна безпека - стан радіаційно-ядерних об'єктів та навколишнього середовища, що забезпечує неперевищення лімітів доз, виключення будь-якого невиправданого опромінення та зменшення доз опромінення персоналу і населення нижче встановлених лімітів доз, настільки, наскільки це може бути досягнуто і економічно обгрунтовано відповідно до вимог «Норми радіаційної безпеки України (НРБУ-97) [8].

Приладне забезпечення. Для виконання робіт 3 радіаційного обстеження території та житлових приміщень м. Жовті Води використовувалися повірені в державних органах метрології і стандартизації України такі прилади та обладнання: дозиметр ДБГ-06Т, радіометри СРП-88Н і IPM, гамма-спектрометр СГC (LP-4900B), радон-монітор AlphaGUARDPQ2000, комплект засобів вимірювальної техніки KBIP-2010Z та ін., що виготовляються на фірмах «Позитрон $\mathrm{GmbH}$ » «Тетра» (Жовті Води) спільно з фірмою «Genitron $\mathrm{GmbH»,}$ (Франфурт-на-Майні, Німеччина) та ін. [9].

Обговорення і оцінка результатів досліджень. Уранова руда видобувається шахтним способом на Жовторічанському промисловому майданчику, що став основним у Східному гірничо-збагачувальному комбінаті (нині ДП «СхідГЗК», Україна). Тут розташована група шахт
(«Вільховська», «Північна-Дренажна», «Капітальна», «Нова», «Нова-Глибока», «Південна-Вентиляційна»). За період з 1951 по 1989 р. балансові запаси уранових руд цілком погашені, i ïх видобуток припинено. Після відпрацьовування уранових руд шахта «Нова» була передана спільному підприємству СП «СхідГЗК-Ашурст» [10-12].

За період експлуатації Жовторічанського родовища сформувалися два кар'єри («Габаєвський» та «Веселоіванівський») та чотири хвостосховища (відпрацьований кар'єр бурих залізняків (КБЗ); балки «Щербаківська» («Щ») (рис. 2); «Разбері» («Р») $\mathrm{i}$ «ернівська» («Т»). Хвостосховища займають більше 3,505 тис. га, на яких накопичено приблизно 50 млн т відходів із загальною активністю 62,1 тис. Ki. Для контролю підземних вод по периметру хвостосховищ балки «Щ» та КБЗ пробурено відповідно 74 і 70 свердловин.

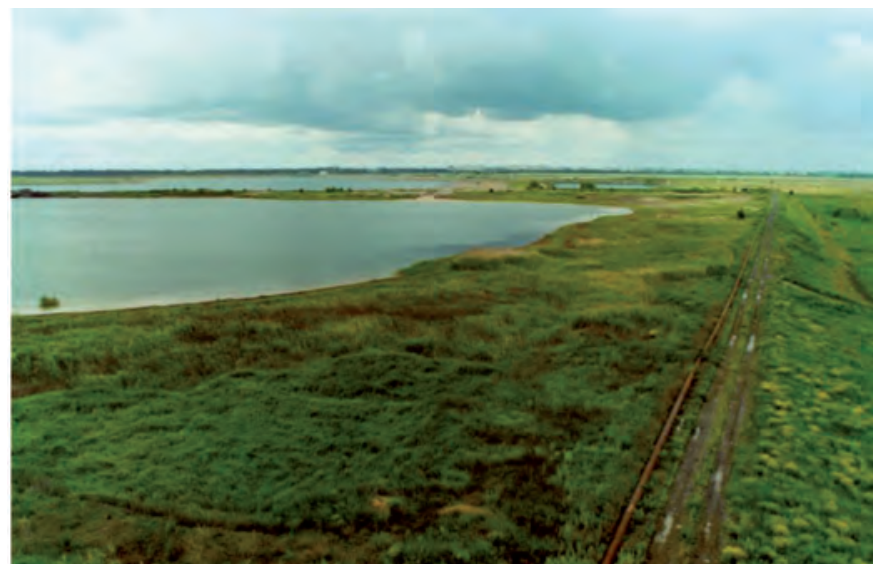

Рис. 2. Загальний вид діючого хвостосховища в балці «Щербаківська» зі складування відходів гідрометалургійної первинної переробки уранових руд

3 півночі на відстані 2 кілометрів поруч один 3 одним розташовані гідрометалургійний завод (ГМЗ) з переробки уранової руди та його резервне «хвостосховище» КБЗ. Технологічною трасою хвостова пульпа від гідрометалургійного заводу з відходами збагачення уранових руд надходить до головного хвостосховища в балщі «Щербаківська» («Щ»), що розташоване з півдня на відстані 1,5 км. Підприємства з видобутку та переробки уранових руд - це потужні джерела радіаційного впливу на навколишнє середовище, що потребує проведення цілого комплексу спеціальних заходів, спрямованих на зниження радіаційного забруднення довкілля, а також на радіаційний та соціальний захист мешканців, які вимушені проживати в зоні техногенного радіаційного впливу (Стусь та ін., 2000) [13-15].

Найбільш небезпечними з радіаційної точки зору є Жовторічанське родовище та зона захоронення радіоактивних відходів у балщі «Разбері» (хвостосховище «Р»), розташованій на лівому 
березі долини р. Жовта, яке використовувалося як накопичувач при скиданні відходів шахти «Нова». Усереднений хімічний склад скидних вод за складом металів та мікроелементів був такий: берилію <0,00005 (гранично припустима концентрація (ГПК) - 0,002), ртуті <0,0005 (ГПК - 0,0005), барію <0,001 (ГПК - 0,1), кобальту < 0,002 (ГПК 0,1), молібдену <0,002 (ГПК - 0,25), миш' яку <0,003 (ГПК - 0,005), нікелю <0,001 (ГПК - 0,1). Інші метали присутні у невеликій кількості: свинець 0,011 мг/л (ГПК - 0,03 мг/л), цинк - 0,08 мг/л (ГПК - 1,0 мг/л). Вміст кадмію перевищував ГПК у два рази в одній із 12 відібраних проб. За усередненими даними зафіксовано 11 ГПК, цинку - 8 ГПК, заліза - 5,8 ГПК. Перевищення ГПК спостерігається за алюмінієм, бромом, залізом, марганцем. Сульфати - 545 мг/л; азот амонійний - 1,28 мг/л; нафтопродукти - 0,04 мг/л. 31992 по 2002 рр. в шахтних водах, за даними СЕС № 9, фіксувалися концентрації урану, що близькі до PC $^{\text {ingest }}$. При цьому вміст урану у р. Жовтій, що протікає неподалік від хвостосховища, складав 0,004-0,039 мг/ л і не перевищував ГПК. Хвостосховище «Р» оконтурене земляною греблею з ущільнених суглинків і глин, природним екраном греблі є глинисті і суглинні грунти. Здреновані освітлені води хвостосховища відводяться у р. Жовту у вигляді дренажного струмка. Річка Жовта, що протікає у східній частині селітебної території м. Жовті Води з півночі на південь, належить до річок категорії господарсько-побутового призначення і не є джерелом питного водопостачання. Шахтні, дренажні, шламові і води р. Жовта разом зі скидами міських каналізаційних очисних споруд потрапляють у р. Інгулець. Радіонуклідний склад вод, отриманий у результаті змішування на цій стадії, визначає якість вод, що потрапляють у розташоване на 1 км вище водосховище «Карачуни» (м. Кривий Ріг). Слід зауважити, що незначне перевищення мінералізації, в основному за рахунок сульфат-іонів, обумовлене природним фактором цього регіону. Природна мінералізація підземних вод водоносного комплексу кристалічних порід, які формують водопритік у шахту та в районі балки «Р», становить від 1500 до 5500 мг/л, сульфатно-натрієвого складу та різноманітні за вмістом сульфатів від 1200 до 2700 мг/л. На підприємстві немає технологій і факторів, які б підвищували вміст сульфатів в оборотній воді. Високий вміст сульфатів р. Жовта пояснюється тим, що зона протікання річки проходить регіоном $з$ підвищеною мінералізацією підземної природної води, яка живить річку.

Хвостосховище «Щ»є джерелом радіоактивного забруднення атмосферного середовища південної частини міста у літній період (рис. 3). Воно розташоване на відстані 1,5 км на південь від м. Жовті Води в межах балки «Щербаківська». Займає площу 256 га. Сховище наливного типу є частиною системи замкнутого водообороту ГМЗ, без стоку у відкриту гідрографічну мережу. Відповідно до проекту організовано перехват дренажних вод огороджувальною греблею, а також перехват і відведення в р. Жовта дощової води 3 площі водозбору балки навколо хвостосховища. За період експлуатації накопичено 27,7 млн т радіоактивних відходів, що містять уран, торій, свинець, полоній загальною активністю $282,2 \times 10^{12}$ Бк (щорічне надходження радіоактивних відходів - 467876,13 т). Радіаційна ситуація в санітарно-захисній зоні балки «Щ» така: потужність дози ү-випромінювання становила від 0,1 до 4,32 мк Зв/год (в середньому - 0,47784 мк Зв/год); сумарна а-активність природних радіонуклідів грунту перебувала в межах від 21,27 до 1106 Бк/ кг; сумарна а-активність у рослинності становила від 2,3 до 170,2 Бк/кг; питома сумарна а-активність природних радіонуклідів у зернових культурах коливалася в межах від 14,4 до 28,7 Бк/кг. Ексхоляція радону з поверхні хвостосховища складає

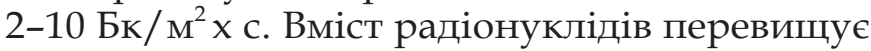
тимчасово припустимий рівень: урану природного - на $11 \%$, радію-226 - на 33 \%, за сумарною а-активністю - на 94,65 \%. Санітарно-захисна зона проектною шириною 1000 м організована, озеленена, режим зони дотримується. Найближче житло розташоване на відстані 1500 м від греблі. Атмосферні опади, які переходять у поверхневий стік, на території ГМЗ практично цілком перехоплюються системою поверхневого водовідводу. Скидання перехоплених поверхневих вод здійснюється у хвостосховище ГМЗ у балщі «Щ». На відстані 2 км на північ від житлової забудови міста, на вододільному плато річок Жовта і Зелена, розташоване відпрацьоване хвостосховище радіоактивних відходів «КБЗ». Площа хвостос-

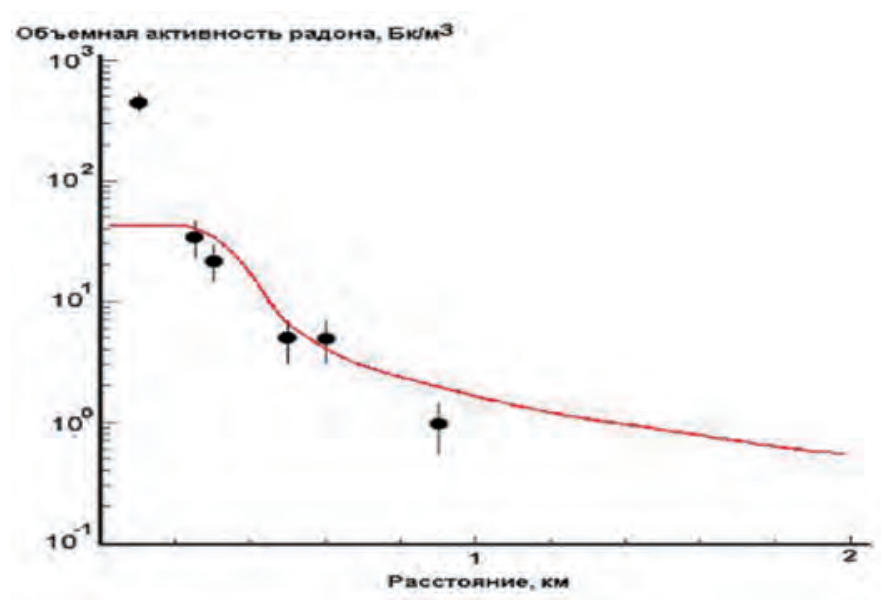

Рис. 3. Залежність об'ємної активності радону в повітрі від відстані для хвостосховища 
ховища складає 54,8 га, об'єм твердих відходів 12,4 млн м ${ }^{3}$. Найближчі населені пункти: 2 км в південному напрямку - м. Жовті Води, в південно-західному - с. Зелений Гай, 1,7 км в східному напрямку в долині р. Жовта - с. Весело-Іванівка. Під хвостосховище використано КБЗ, який складається 3 малої чаші глибиною 10-15 м і великої чаші глибиною 60-65 м. Кар'єр використовувався під складування відходів без спеціальних протифільтраційних заходів. Складування хвостового матеріалу, що являє собою відходи переробки уранових руд, планомірно провадилося у період з 1964 по 1982 рр. шляхом гідроналивання. У його чашу покладено 15,944 млн т хвостів. Загальна активність складає $93,3 \times 10^{12}$ Бк. Проектна санітарно-захисна зона шириною 500 м організована, режим зони дотримується. Велика частина поверхні хвостосховища з метою запобігання негативному впливу на навколишнє природне середовище покрита ізолюючим прошарком (шаром глинозему товщиною 70 см, та закріплена шаром кварциту товщиною 20 см), а на частині, що залишилася, $\epsilon$ ставок, який використовується як резервна ємність. У промзоні міста, в його північній частині, розташований ГМЗ. Жовті Води з усіх сторін оточені радіаційно-небезпечними об' єктами. Робота і розташування цих об'єктів спричиняють (викиди в атмосферу, відвали твердих відходів, скидання стічних вод) шкідливий вплив ряду виробничих чинників на навколишнє природне середовище і населення міста, що складає біля 45 тис. чол.

Видобуток та первинне збагачення уранових руд стало специфічною особливістю формування радіаційної обстановки в м. Жовті Води (Ю. Н. Сорока, 1997) і першим джерелом радіоекологічного забруднення Придніпров'я. Це призвело до утворення 550 тис. м $^{3}$ відвалів пустих порід і позабалансових руд та порушення 968 га родючих земель. На стан радіоекологічного забруднення Придніпров'я (забруднення регіону радіонуклідами ${ }^{137} \mathrm{Cs},{ }^{90} \mathrm{Sr}$ ) негативно вплинула Чорнобильська катастрофа (1986 р.) як третє джерело радіоекологічного забруднення Придніпров' я. У результаті цього в регіоні відбулося накопичення природних та штучних радіонуклідів.

Історично склалася ситуація, коли населення в межах міста Жовті Води було змушене постійно жити в зоні радіаційного забруднення, яке перевищує норми, встановлені НРБУ-97 [8]. За результатами досліджень повітря на радіаційні показники встановлено, що відносно фонових величин та встановлених нормативів концентрація радіонуклідів значно зменшується із зростанням відстані від греблі хвостосховища та огорожі ГМЗ. На межі С33 та в зонах спостереження концентрація радіонуклідів в основному перебуває на нижній межі вимірювання.
На формування радіаційного становища в місті вплинуло забруднення доріг, тротуарів, житлових будинків, шкіл та дитсадків, інших споруд і приміщень гірничими породами, які містили радіоактивні матеріали, що негативно впливає на навколишнє середовище та мешканців міста (А. В. Люлько та ін., 1996; Н. Н. Моїсеєнко та ін., 1996; Ляшенко, 1993, 1995, 1996, 2001). У результаті на території міста Жовті Води утворилися окремі локальні (до 450) ділянки з радіаційним фоном 40-500 мкр/год (природний фон становить 1522 мкр/год). За даними відомчої лабораторії радіоактивне забруднення грунту навколо м. Жовті Води (на відстані від 10 до 40 км) не перевищує фонових значень за сумарною а-активністю і складає: м. П'ятихатки - 1776 Бк/кг, с. Комісарівка - 1443, с. Ерастівка, метеостанція - 2220, с. Жовте - 2553 Бк/кг.

Забруднення грунту природними радіонуклідами $з$ перевищенням фонових показників реєструється в межах С33 на ділянках, безпосередньо прилеглих до греблі сховищ або огорожі ГМЗ по ходу пульпопроводу. На межі С33 максимальна активність природних радіонуклідів у грунті складає 146,5 Бк/кг, а максимальний результат атмосферних опадів складає 1,243 Бк (м²/ добу), що не перевищує контрольний рівень 7,4 Бк ( $\mathrm{M}^{2} /$ добу). За результатами дослідження підземних вод у мережі спостереження свердловин підвищення концентрації природних радіонуклідів не виходить за межі С33 і реєструється на межі огороджувальних гребель хвостосховищ та на території ГМЗ. Забруднення рослинності складає: калій-40 - 308-412 Бк/кг, торій-232 - 3,0-3,7, уран238 - 1,5-3,4 Бк/кг; потужність експозиційної дози (ПЕД) - 13,0 мкР/год [16-18].

В умовах м. Жовті Води працівники основного виробництва та населення міста отримують додаткову дозу радіаційного опромінення (В. И. Ляшенко, 1994: А. В. Люлько та ін., 1996), а також зазнають комбінованого впливу відходів - пилу уранової руди, радону та продуктів його розпаду (рис. 4). Зокрема виявлено забруднення грунтів, води та атмосферного повітря такими радіонуклідами, як уран-238, радій-236, свинець-210 і полоній-210. У поверхневому шарі грунту концентрація урану-238 перевищує фонову в 2-7 разів, радію-226 - у 2-9, свинцю-210 - у 2-25, полонію-210 - в 2-17 разів. У місті накопичено близько 50 млн т відходів, у тому числі 1,4 млн т токсичних I-IV класів небезпеки. Перевищення подвійного нормативу концентрації радону в житлових приміщеннях становить $9 \%$, а в приватному секторі понад 21 \%, що у кілька разів перевищує норми НРБУ-97 [8]. Лише за вибірковими даними Українського наукового центру радіаційної медицини (м. Київ) у 42 \% обстежених будинків у м. Жовті 


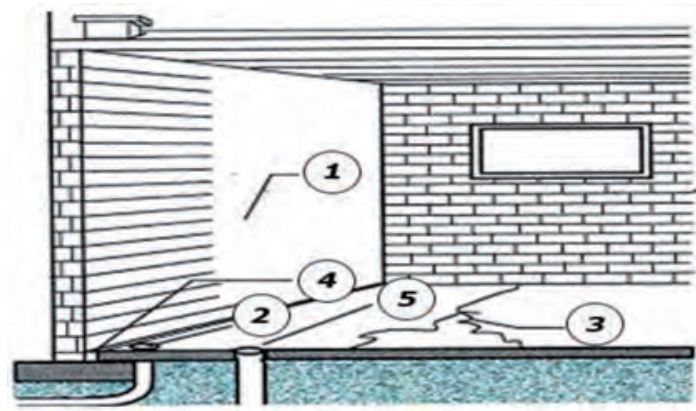

Рис. 4. Схема шляхів проникнення радону в приміщення: 1 - блокові стіни; 2 - каналізаційна труба; 3 - тріщини в підлозі; 4 - місце стику стін 3 підлогою; 5 - стічний колодязь

Води еквівалентна рівноважна об'ємна активність радону перевищила регламент $(100$ Бк/м³) для будівель, що експлуатуються. Значною проблемою не тільки міста, але й усього регіону є утилізація та захоронення джерел іонізуючого випромінювання на ВАТ «Електрон-Газ», де зберігається 17996 одиниць джерел іонізуючого та нейтронного випромінювання сумарною активністю 14675 Ki, більшу частину яких розміщено ще у 90-х роках минулого сторіччя [19-21].

Навіть у малих дозах вплив іонізуючої радіації викликає мутагенний, імуносупресивний та цитотоксичний ефекти (В. А. Зайцев та ін., 1992; В. Н. Шубік 1992; В. H. Erickson, G. G. Hall, 1983), передчасне старіння (B. Н. Чернишов та ін., 1992), порушення функції усіх органів, у тому числі сім'яників (D. K. Clifton, W. J. Bremner, 1983; M. I. Meistrich, R. C. Sumuels, 1985; B. M. Cattanach, C. Rasberry, 1986). Джерела іонізуючого випромінювання згубно діють на статеві клітини, пригнічують активність стероїдних гормонів та синтез рецепторних білків, викликаючи загальне пригнічення гонадотропної активності та порушення сперматогенезу. Відзначається зростання імунодефіцитних станів, автоімунних захворювань, онкопатології, несприятливого перебігу вагітності та пологів, зростання урологічних патологій. У структурі розповсюдженості захворювань перше місце займають хвороби органів дихання та кровообігу, друге - системи травлення, третє - захворювання сечостатевих органів (В. П. Стусь). Захворюваність населення має стійку тенденцію до зростання. Зокрема в місті рівень захворюваності інфарктом міокарду та хронічним бронхітом перевищує середньообласні показники в 2 рази (Ю. А. Солонько та ін., 1995). Населення міста скорочується темпами, більшими ніж у середньому по Україні в 2,1 разу (майже на одну тисячу чоловік щорічно). Рівень онкологічних захворювань зріс майже в 2 рази у чоловіків (переважно за рахунок раку легень, шлунку та кишок) та в 1,3 разу у жінок (в основному за рахунок раку молочної залози). Онкологічна захворюваність і смертність в м. Жовті Води найвища в Дніпропетровській об- ласті і перевищує середні показники по Україні. Захворюваність на туберкульоз майже в 2 рази перевищує середньообласні. Відзначається також високий рівень вроджених аномалій у дітей.

Для зниження концентрації радону в повітрі приміщень проводять роботи для кожного житлового будинку, виходячи з його об'ємнопланувальних і конструктивних рішень і концентрації радону. і . Ці роботи виконують після вилучення аномальних включень 3 конструктивних елементів будинків, вони поділяються на три види: вентиляційні, ізоляційні, комбіновані (рис. 5). Вентиляційні заходи включають вентилювання приміщень, технічних поверхів і підвалів за ïx наявності. Тип вентиляції, кратність повітряного обміну і повітропроводів визначається розрахунком. Ізоляційні заходи включають утворення шару між грунтом основи і конструкцією підлоги, без зменшення будівельного обсягу житлового будинку. Ці роботи виконуються з обов' язковим відселенням мешканців приміщення або будинку в цілому. Ізоляційний шар у підлогах житлових будинків проводиться зі зняттям існуючої підлоги, поглибленням простору підлоги, утворенням герметизуючого шару із закладенням його в тіло фундаменту, відновленням конструкцій підлоги і упорядкуванням приміщень. Комбінований засіб передбачає об'єднання заходів з вентиляції приміщень 3 обладнанням ізолюючого шару. Протирадонові заходи виконані в окремих приміщеннях Жовтоводського промислового технікуму, Науково-технічного центру з дезактивації та комплексного поводження з радіоактивними відходами та джерелами іонізуючого випромінювання (НТЦ «КОРО»), реконструйованого будинку по вулиці Паркова, 18 під житло і в окремих дитячих дошкільних закладів міста.

Враховуючи зазначені обставини, уряд України прийняв спеціальну постанову, згідно з якою затверджено Державну програму заходів щодо радіаційного та соціального захисту населення м. Жовті Води Дніпропетровської області (Постанова Кабінету Міністрів України від 8 червня 1995 року № 400) [22-23].

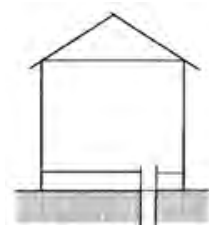

a)

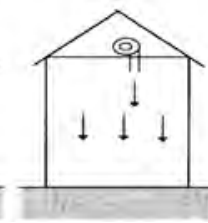

б)

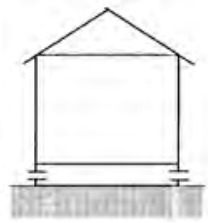

B)

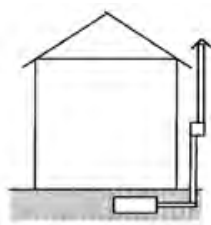

г)
Рис. 5. Схеми шляхів зниження вмісту радону в повітрі житлових приміщень:

а - герметизація перекриттів під підлогою (ізоляція);

б - створення підвищеного тиску всередині приміщення; в - вентиляція під підлогою; г - зменшення тиску під підлогою 


\section{Основними завданнями Програми стали:}

- створення та забезпечення функціонування системи постійного спостереження та контролю за станом навколишнього природного середовища, у тому числі радіаційним і медико-біологічним станом;

- проведення робіт з оздоровлення навколишнього природного середовища на території міста;

- забезпечення радіаційної безпеки та запобігання виникненню надзвичайних ситуацій техногенного характеру;

- приведення радіаційного фону в житлових, громадських приміщеннях, будівлях, спорудах до рівня, визначеного нормами НРБУ-97, надання населенню, житло якого неможливо привести до норм НРБУ-97, нового житла;

- забезпечення додаткового харчування і оздоровлення дітей та надання матеріальної допомоги жителям, які мешкають на територіях 3 незадовільним екологічним станом і підвищеним радіаційним фоном;

- надання додаткової медичної допомоги дітям, вагітним жінкам і породіллям, громадянам, що мають пільги, визначені законодавством;

- розвиток мережі лікувально-профілактичних закладів та забезпечення їх функціонування.

Подальше проведення заходів щодо радіаційного та соціального захисту населення м. Жовті води регулюється:

- Постановою КМ України від 05.05.2003 р. № 656 «Про затвердження Програми радіаційного і соціального захисту населення м. Жовті Води на 2003-2012 роки».

- Постановою КМ України від 25.06.2012 р. № 579 «Про затвердження Програми радіаційного і соціального захисту населення м. Жовті Води на 2013-2022 роки» [24].

Розвиток програми радіаційного та соціального захисту населення міста

У зв'язку з недостатнім бюджетним фінансуванням уряд України продовжував вищезазначену Програму двома відповідними постановами КМУ від 05 травня 2003 року № 656 - на 2003 2012 рр. та від 25 червня 2012 року. № 579 - на 2013-2022 рр. Комплекс робіт з реабілітації забрудненої території міста передбачає вирішення завдань із загальним бюджетним фінансуванням України, понад 200 млн грн, включаючи проведення комплексу робіт з реабілітації забрудненої території міста для зниження дозових навантажень на населення та посилення соціального захисту населення, що мешкає на територіях 3 підвищеним радіаційним фоном [25; 26].

Перспективи подальших досліджень. На території санітарно-захисної зони (С33) Інгульської шахти ДП «СхідГЗК» (м. Кропивницький) дозиметричні виміри ПЕД випромінювання про- водили по периметру кожного відвалу порожніх і забалансових порід, на відстані 2-3 м від відвалу (рис. 6). На ділянці, де спостерігається поверхневий стік вод, радіаційний фон у середньому становить 0,3 мкЗв/год і доходить до рівня від 1,07 до 1,59 мкЗв/ год, а в деяких місцях у 8-13 разів перевищує допустимий і контрольний рівні. Це свідчить про радіоактивне забруднення території біля підніжжя відвалів і неможливість використання цієї території для інших народногосподарських цілей. Крім того, є небезпека розповсюдження радіоактивного пилу від відвалів природними (вітром, дощовими і талими водами) і техногенними (автотранспортом) факторами. Для підтвердження вищевказаних аргументів було проведено дозиметричне обстеження берега річки Інгул, межі санітарно-захисної зони (С33) 3 прилеглими територіями, дороги за маршрутом автотранспортних перевезень і біля населеного пункту. Для виявлення радіоактивного забруднення поверхневим стоком дощової і талої води з відвалів було проведено дозиметричне обстеження берега річки. Вимірювання ПЕД проводилося по лівому берегу на відстані 1-2 м від річки, вниз за течією. Дослідженню підлягала та частина річки, яка протікала територією С33 зазначеної шахти.

Шляхи подальших досліджень. Аналіз показує, що підприємства атомної промисловості впливають на радіоекологічний стан навколишнього природного середовища та населення [21]. Для профілактики шкідливого впливу радіаційного забруднення на людину необхідне систематичне спостереження за вмістом ПРН та важких металів в об'єктах навколишнього середовища та продуктах харчування. За допомогою проектів МАГАТЕ, Двосторонньому співробітництву $з$ Норвегією, Швецією і США в Україні, Російській Федерації, країнах Центральної Азії розробляються заходи з гармонізації та удосконалення вимог і критеріїв, спрямованих на підтримку планування і здійснення реабілітаційних програм. Ефективність виконання реабілітаційних заходів суттєво залежить від наявності відповідних національних стратегій екологічної безпеки, нормативних вимог та регуляторних механізмів, а також досвіду управління подібними проектами відповідно до міжнародних стандартів.

\section{Висновки}

1. Встановлено радіаційне забруднення територій та споруд міста Жовті Води, виявлено 5368 аномалій з потужністю експозиційної дози вище 50 мкР/год, у тому числі 71 \% аномалій, які спостерігаються на території домовласництв приватного сектора, у фундаментах житлових будинків - 1174 аномалії; у 70,5 \% будинків приватного сектора еквівалентна рівноважна концен- 


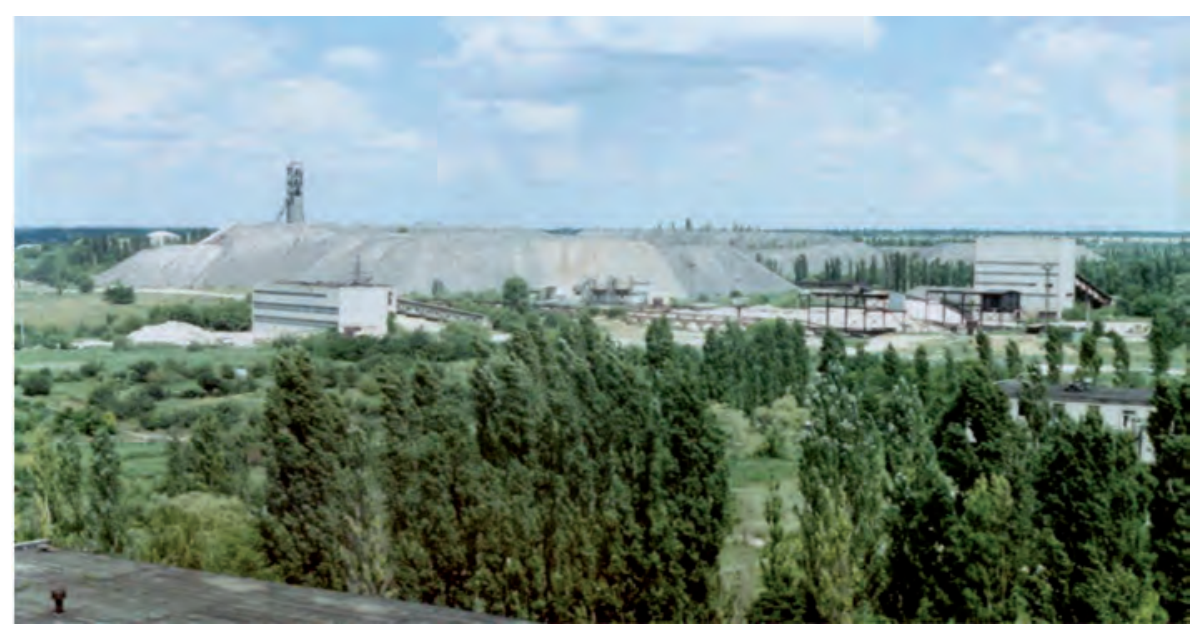

a)

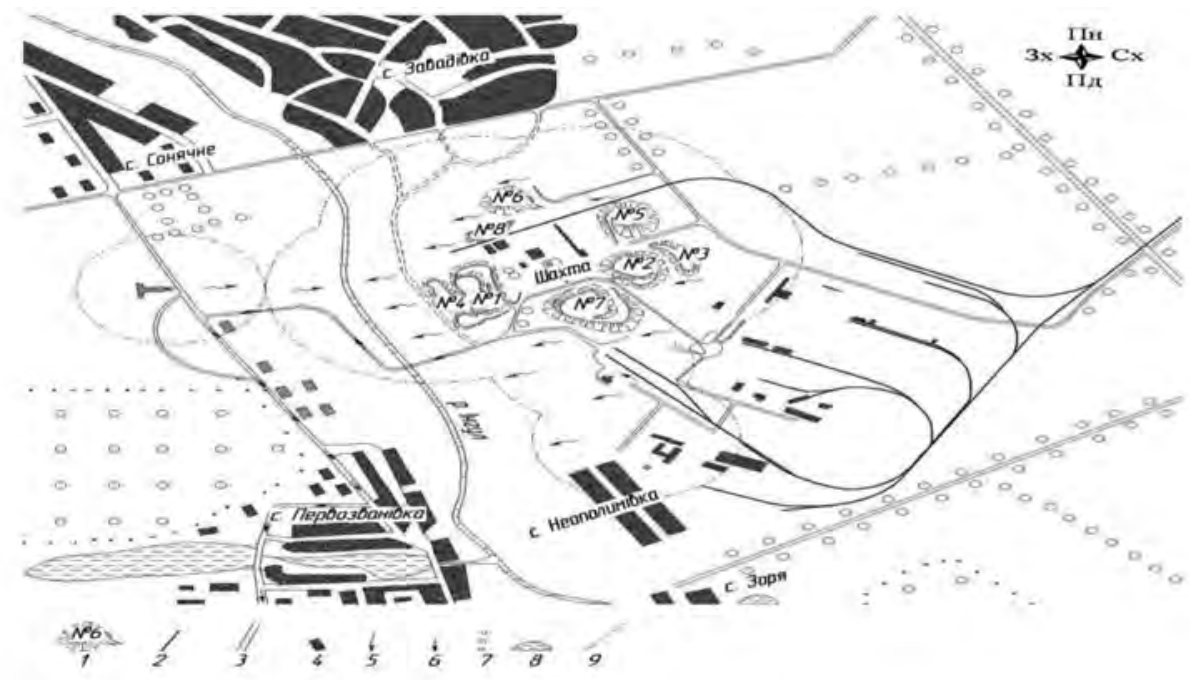

б)

Рис. 6. Промисловий майданчик шахти «Інгульська», м. Кропивницький:

а - фото закладного комплексу: загальний вигляд відвалів порожніх порід і позабалансових за змістом корисних компонентів, руд); б - схема прилеглої території: 1 - відвал і його номер; 2 - залізниця;

3 - асфальтна дорога; 4 - будівлі, житлові квартали селищ; 5 - напрямок стоку поверхневих вод р. Інгул; 6 - напрямок руху автотранспортних перевезень; 7 - рослинні насадження; 8 - водойми;

9 - санітарно-захисна зона

трація (ЕРК) радону та дочірніх продуктів його розпаду понад 100 Бк / м³ ; серед 2625 обстежених житлових будинків середнє значення ЕРК радону

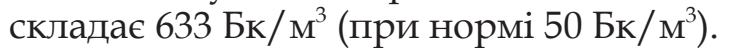

2. Показано, що перевищення нормативного рівня еквівалентної рівноважної об'ємної активності радону 50 Бк/ ${ }^{3}$ в окремих приміщеннях обумовлене його виділенням з простору під підлогою та каналу введення зовнішньої теплової та водопровідної мережі, внутрішніх каналів розподілу тепломережі.

3. Пропонуються заходи щодо зменшення активності радону в повітрі приміщень шляхом заповнення каналу теплової мережі із зовнішнього боку будівлі шаром глини на глибину 1 м і його ущільнення, герметизації введення теплової та водопровідної мережі через фундамент будівлі та бетонування каналів, що зменшує об'ємну активність радону в приміщенні в 5-6 раз. Повна герметизація підлоги поліетиленовою плівкою або іншими матеріалами, ізоляція окремих місць підведення комунікацій і поверхні грунту бетонним покриттям разом з поліетиленовою зменшує активність радону в повітрі до двох разів.

4. Рекомендована система радіаційного моніторингу уранових об'єктів на базі приладів та автоматизованих систем нового покоління. Система радіаційного моніторингу включає чотири спостережних пости на річках Жовта та Зелена, спостережні свердловини на території ГМЗ, що дозволяє уточнити площу забруднення водоносних горизонтів.

Роботу виконано за результатами доповіді на XIV Міжнародної науково-практичної конференції «Екологічна безпека: проблеми і шляхи вирішення» (м. ХаркіВ, 10-14 Вересня 2018 р.) [27]. 
Бібліографічний список / References

1. Арапов Ю. А. Урановые месторождения Чехословакии / Ю. А. Арапов, В. Е. Бойцов. - М.: Недра, 1984. - 445 с.

Arapov Ju. A., Bojzov B. E. (1984). Uranovie mestorogdenij Czechoslovakii [Uranium deposits of Czechoslovakia]. Moscow, Nedra, 445 p. (In Russian).

2. Норми радіаційної безпеки України (НРБУ97) від 01.12.97 № 62. - К.: 1997. - 127 с.

Norms of radiation safety of Ukraine (NRBU-97) of December 01, 1997 no. 62. Kyiv, 1997, 127 p. (In Ukraine).

3. Добыча и переработка урановых руд: монография / под общ. ред. А. П. Чернова. - К.: АдефУкраина, 2001. - 238 с.

Chernov A. P. (Ed.) (2001). Dobycha i pererabotka uranovyh rud [Mining and processing of uranium ores]. Kiev, Adef-Ukraina, 238 p. (In Ukraine).

4. Карамушка В. П. Рекультивация объектов добычи и переработки урановых руд / В. П. Карамушка, Е. Н. Камнев, Р. 3. Кузин. - М.: Горная Книга. - 2014. - 183 с.

Karamuschka V. P., Kamnev E. N., Kusin R. Z. (2014). Rekultivazij obektov dobitchi I pererabotki uranovich rud. Moscow, Gornaj kniga, 183 p. (In Russian).

5. Коваленко Г. Д. Радиоэкология Украины / Г. Д. Коваленко. - Х.: ИНЖЕК, 2013. - 344 с.

Kovalenko G. D. (2013). Radiotkologij Ukraine [Radyoekolohyya Ukraine]. Kharkiv, INGEK, 344 p. (In Ukraine).

6. Лисиченко Г. В. Мировой опыт реабилитации урановых производств / Г. В. Лисиченко, В. Е. Ковач / / Техногенно-экологическая безопасность и цивильная защита. - Кременчуг. - 2011. Вып. 6. - С. 4-12.

Lysychenko G., Kovach V. (2011). Mirovoj opit reabilitazii uranovich proisvodsto [World experience of uranium production rehabilitation]. Technogennoekologitcheskaj besopasnost $i$ zivilnaj saschita, issue. 6, pp. 4-12 (in Ukraine).

7. Ляшенко В. И. Радиационная и социальная защита населения в регионах уранодобывающих и перерабатывающих производств Украины / В. И. Ляшенко / / Безопасность труда в промышленности. - 2013. - № 2. - С. 55-62.

Lyashenko V. I. (2013). Radiazionnaj i sozialnaj saschita naselenij $v$ regionach uranodobuvayuschyh $i$ pererabatblvayuschyh proisvodsto Ukraine [Radiation and Social protection of population in the regions and uranodobyvayuschyh pererabatyvayuschyh productions Ukraine]. Bezopasnost' truda v promyshlennosti, no. 2, pp. 55-62.

8. Ляшенко В. И. Повышение экологической безопасности в зоне влияния уранового производства / В. И. Ляшенко / / Известия ВУЗов. Геология и разведка. - 2015. - № 1. - С. 43-52.
Lyashenko V. I. (2015). Povischenie ekologitscheskoj bezopasnosti $v$ sone vlijnij uranovogo proisvodstva [Increase of ecological safety in the zone of influence of uranium production]. Izv. VUZov. Geologij I rasvedka, no. 1, pp. 43-52.

9. Ляшенко В. И. Радиационный мониторинг объектов урановой промышленности Украины / В. И. Ляшенко / / Известия ВУЗов. Геология и разведка. - 2015. - № 6. - С. 74-83.

Lyashenko V. I. (2015). Radiazionnyj monitoring objectov uranovoj promischlennisti Ukraine [Radyatsyonnyi monitoring objects uranium industry of Ukraine]. Izv. VUZov. Geologij I rasvedka, no. 6, pp. 74-83.

10. Ляшенко В. И. Экологическая безопасность уранового производства в Украине / В. И. Ляшенко / / Горный журнал. - 2014. - № 4. - С. 113-116.

Lyashenko V. I. (2014). Ekologitcheskaj bezopasnost' uranovogo proisvodstva v Ukraine [Environmental safety of uranium production in Ukraine]. Gornyj zhurnal, no. 4, pp. 113-116.

11. Розпорядження Кабінету Міністрів України № 145-р від 15.03.2006 р. Про схвалення Енергетичної стратегії України на період до 2030 року [Електронний ресурс]. - Режим доступу: http:/ / zakon2.rada.gov.ua/laws/show/145-2006-\%D1\%80.

Rosporjdgenj Kabinetu Ministriv Ukraine № 145r vid 15.03.2006 "Pro schvalennj Energetitchnoi strategii Ukraine na period do 2030 roky" [Cabinet of Ministers of Ukraine no. 145-p of 15.03.2006. On approval of the Energy Strategy of Ukraine until 2030]. Available at: http:/ / zakon2.rada.gov.ua/ laws/show/145-2006-\%D1\%80.(in Ukraine).

12. Розпорядження Кабінету Міністрів України № 616-р: редакція від 31.05.2017 р. «Про схвалення Концепції реформування системи державного нагляду (контролю) у сфері охорони навколишнього природного середовища».

Rosporjdgenj Kabinetu Ministriv Ukraine no. 616r: redakzij vid 31.05.2017 r. "Pro schvalennj Konzepzii reformuvannj sistemi dergavnogo nahljdu (kontroly) u sferi ochoroni navkolischnygo prirodnogo seredovischa" (in Ukraine).

13. Санитарные правила 2.6.1.2612-10. Основные санитарные правила обеспечения радиационной безопасности (ОСПОРБ-99/2010) (с изм. от 16.09.2013 г.); Минздрав России, 2010. - 79 с.

Sanitarnie pravila 2.6.1.2612-10. Osnovnie sanitarnie pravila obespetchenij radiazionnoj bezopasnost'I (OSPORB-99/2010) (s ism. ot 16.09.2013 g.) (2010) [Sanytarnye 2.6.1.2612-10 rules. Basic rules sanytarnye Provision radiation safety (OSPORB-99/2010) (c amended. From 09.16.2013)]. Minsdrav Rossii, 79 p. (In Russian).

14. Ляшенко B. I. Екологічна безпека уранового виробництва / В. І. Ляшенко, Ф. П. Топольний, 
М. І. Мостіпан, Т. С. Лісова. - Кіровоград: КОД, 2011. - 240 c.

Lyashenko V. I., Topolnia F. F., Mostipan M. I., Lisova T. S. (2010). Ekologitcheskaj bezopasnost' uranovogo proisvodstva [Environmental safety of uranium production]. Kirovograd, KOD, 215 p. (In Ukraine).

15. Стусь В. П. Экология окружающей среды и безопасность жизнедеятельности населения в промышленном регионе / В. П. Стусь, В. И. Ляшенко / / Экология и промышленность. - 2011. № 2. - C. 23-31.

Stus' V. P., Lyashenko V. I. (2011). Ecologia okruschajschej sredi i bezopasnost' zhiznedejatel'nosti naselenia $v$ promischlennom regione [Ecology of the surrounding area and the safety of the livelihoods of the population in the most developed region]. Ecologia i promischlennost', no. 2, pp. 23-31.

16. Сердюк А. М. Екологія довкілля та безпека життедіяльності населення у промислових регіонах України / А. М. Сердюк, В. П. Стусь, В. І. Ляшенко. Дніпропетровськ: Пороги, 2011. - 486 с.

Serduk A. M., Stus' V. P., Lyashenko V. I. (2011). Ecologia dovkilj ta bespeka schitedijlnosti naselenj $u$ promislovich regionach Ukraine [Ecology of the environment and life safety of the population in industrial regions of Ukraine]. Dnipropetronsk, Porogi, 486 p. (In Ukraine).

17. Стусь В. П. Безопасность жизнедеятельности населения в уранодобывающих регионах Украины / В. П. Стусь, В. И. Ляшенко / / Безопасность жизнедеятельности. - 2016. - № 6. - С. 16-21.

Stus' V. P., Lyashenko V. I. (2013). Bezopasnost' zhiznedejatel'nosti naselenia v uranodobivajschich regionach Ukraine [Safety of life of the population in uranium-producing regions of Ukraine]. Bezopasnost' zhiznedejatel'nosti, no. 12, pp. 41-47.

18. Стусь В. П. Повышение безопасности жизнедеятельности населения в промышленных регионах / В. П. Стусь, В.И.Ляшенко / / Горный информационно-аналитический бюллетень. 2017. - № 5. - C. 198-215.

Stus' V. P., Lyashenko V. I. (2017). Povischenie bezopasnosti zhiznedejatel'nosti naselenia $v$ promischlennich regionach [Increasing the safety of the population's life in industrial regions]. Gornij informazionno-analititchskia bjlleten', no. 5, pp. 198-215.

19. Ляшенко В. И. Повышение радиационной безопасности на основе надежного системного и приборного обеспечения / В. И. Ляшенко, С. П. Зонов, Г. Д. Коваленко / / Екологічна безпека: проблеми і шляхи вирішення: зб. наук. статей XIII Міжнародної науково-практичної конференції (м. Харків, 11-15 вересня 2017 р. / УКРНДІЕП. - Х.: Райдер, 2017. - С. 263-274.

Lyashenko V. I., Sonov S. P., Kovalenko G. D. (2017). Povischenie radiazionoj bezopasnosti na osnove nadeschnogo sistemnogo I pribornogo obespetchenij
[Increase of radiation safety on the basis of reliable system and instrumentation]. Sbornik trudov XIII Megdunarodnoj nautchno-praktitcheskoj konferenzii, 11-15 September 2017, Charkov, GP UKRNDIEP, Rajder Pubi., pp. 263-274 (in Ukraine).

20. Ляшенко В. И. Повышение радиационной безопасности на основе надежного системного и приборного обеспечения / В. И. Ляшенко, С. П. Зонов, Ф. Ф. Топольный, Г. Д. Коваленко / / Металлургическая и горнорудная промышленность. - 2017. - № 6 (309). - С. 81-88.

Lyashenko V. I., Sonov S. P., Topolnia F. F., Kovalenko G. D. (2017). Povischenie radiazionoj bezopasnosti na osnove nadeschnogo sistemnogo I pribornogo obespetchenij [Increase radiation safety on the basis of reliable system and instrumentation]. Metalurgitcheskaj I gornorudnaj promischlenost', no. 6 (309), pp. 81-88.

21. Ляшенко В. И. Повышение экологической безопасности и защита населения в уранодобывающих регионах Украины. Проблемы и пути их решения / В. И. Ляшенко, В. П. Стусь, Т. С. Лисовая / / Маркшейдерия и Недропользование, 2018, no. 3 (95), pp. 41-48.

Lyashenko V. I., Stus' V. P., Lisova T. S. (2018). Povischenie ekologitscheskoj bezopasnosti i zaschita naselenia $v$ uranodobivajschich regionach Ukraini. Problemi i puti ich reschenij [Increasing the safety of the population's life in industrial regions]. Markschejderij i Nedropol'sovanie, no. 3, vol. 95, pp. 41-48.

22. Kulik L., Stemann H. (2014). Ecology and biodiversity protection in the Rhenish lignite mining area. World of Mining - Surface \& Underground. Vol. 66 (3), pp. 143-152.

23. Lauer N. E., Hower J. C., Hsu-Kim H., Taggart R. K., Vengosh A. (2015). Naturally occurring radioactive materials in coals and coal combustion residuals in the united states / / Environmental Science \& Technology. - Vol. 49. - No. 18. -Pp. 1122711233.

24. Pulz K. (2014). Meeting the challenges and implementingthe management objectives of lignite mining rehabilitation. World of Mining - Surface \& Underground. - Vol. 66 (3), pp. 153-159.

25. Wang C., Feng Q., Sun R., Liu G. (2015). Radioactivity of Natural Nuclides (40K, 238U, 232Th, 226Ra) in Coals from Eastern Yunnan, China // Minerals. - No. 5. - Pp. 637-646.

26. Коваленко Г. Д. Оценка радиационной опасности хвостохранилиш Приднепровского химического завода для населения / Г. Д. Коваленко, Н. С. Дураcoba // Ядерная и радиационная безопасность. 2015. - № 3. - C. 49-53.

Kovalenko G. D., Durasova N. S. (2015). Estimation of radiation hazard of the dump ponds of. Nuclear and radiation safety. No. 3, pp. 49-53.

27. Дворецький А. І. Вплив уранової промисловості Придніпров'я на стан довкілля. Пробле- 
ми та шляхи їх вирішення / А. І. Дворецький, В. І. Ляшенко, В. П. Стусь, Г. Д. Коваленко // Екологічна безпека: проблеми і шляхи вирішення: зб. наук. статей XIV Міжнародної науковопрактичної конференції (м. Харків, 10-14 вересня 2018 р.) / УКРНДІЕП. - Х.: ФОП Столярова І. П., 2018. - C. 156-165).

Dvorezkij A. I., Lyashenko V. I., Stus' V. P., Kovalenko G. D. (2018). Povischenie radiazionoj bezopasnosti na osnove nadeschnogo sistemnogo I pribornogo obespetchenij [Increase of radiation safety on the basis of reliable system and instrumentation]. Sbornik trudov XIV Megdunarodnoj nautchnopraktitcheskoj konferenzii, 11-15 September 2017, Charkov, GP UKRNDIEP, Rajder Publ., pp. 263-274 (in Ukraine).

Цель. Дать оценку влияния урановой промышленности на состояние окружающей среды и населения на основе разработки и внедрения инженерно-технических решений и мероприятий по уменьшению v-излучения и концентрации радона в помещениях, выполнению экологической и социально-бытовой реабилитации загрязненной территории, жилых домов, объектов социальной сфреры и населения, проживающего в зоне влияния, для повышения экологической безопасности окружающей среды и населения, минимизации негатива воздействия радиационных и других фракторов.

Методика. Использованы радиометрические методы (измерение экспозиционной дозы и интенсивности ү-излучения, измерение радиоактивности $\gamma$ - $u$ $\beta$-излучения, измерение мощности экспозиционной дозы ү-излучения, определение мощности поглощенной дозы ү-излучения в воздухе, анализ природных радионуклидов (ПРН); статистический и математический методы исследования с использованием комплексного системного подхода. Радиоэкологические исследования включали: измерения мощности экспозиционной дозы (ПЭД) ү-излучения с сетью 100×100 м и 20×10 м (пешеходная ү-съемка) в объеме 40 км², анализ почв на содержание радионуклидов; отбор проб воды на содержание радия и урана, определение суммарной $\alpha$ - и $\beta$-активности почв, определение концентрации радона в жилых помещениях.

Результаты. Показана роль специалистов различных органов государственной власти и местного самоуправления в решении вышеупомянутых задач для регионов, находящихся в зоне влияния горнометаллургических комбинатов по добыче и первичной переработке урановых руд. Установлено, что превышение нормативного уровня эквивалентной

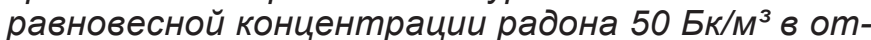
дельных помещениях обусловлено его выделением из подпольного пространства и каналов ввода внешней тепловой и водопроводной сетей, внутренних каналов распределения теплосетей.

Научная новизна. Доказывается, что засыпка канала тепловой сети с внешней стороны здания слоем глины на глубину 1 м и его уплотнение, герметизация ввода тепловой и водопроводной сетей через фунндамент здания и бетонирование приямка уменьшают объемную активность радона в помещении в 5-6 раз.
Практическая ценность. Приведен пока редкий опыт по повышению радиационной и социальной защиты населения города Желтые Воды, проживающего в зоне влияния объектов урановой промышленности.

Ключевые слова: радиоэкология, урановое производство, государственные программы, природоохранные мероприятия, радиационная и социальная защита населения.

Purpose. To assess the impact of uranium industry on the environment and population on the basis of the development and implementation of engineering and technical solutions and measures to reduce gamma radiation and radon concentration in the premises, to carry out environmental and social rehabilitation of the contaminated area, residential buildings, social facilities and the population living in the zone of influence aimed at increasing the environmental safety of the environment and population in order to minimize the negative effects of radiation and other factors.

Methodology. Radiometric methods used (measurement of exposure dose and intensity of $\gamma$ radiation, measurement of radioactivity of $\gamma$ - and $\beta$-radiation, measurement of the exposure dose rate of $\gamma$-radiation, determination of the power of absorbed dose of $y$-radiation in air, analysis of natural radionuclides $(P R N)$, statistical and mathematical research methods using a comprehensive system approach. Radioecological studies included: measurement of the exposure dose (ED) power of gamma radiation over the network of $100 \times 100 \mathrm{~m}$ and $20 \times 10 \mathrm{~m}$ (pedestrian $\mathrm{y}$-survey) in the volume of $40 \mathrm{~km}^{2}$, analysis of soils on the content of radionuclides, sampling of water for the content of radium and uranium, determination of total $\alpha$ - and $\beta$-activity of soils, determination of radon concentration in residential premises.

Findings. The role of specialists of various state authorities and local self-government in solving the abovementioned tasks is shown for the regions located in the zone of influence of mining and metallurgical combines on extraction and primary processing of uranium ores. It was established that exceeding the standard level of equivalent equilibrium radon concentration of $50 \mathrm{~Bq} / \mathrm{m}^{3}$ in separate premises is due to its allocation from underground space and channels of introduction of external thermal and water supply networks, internal channels of distribution of heating networks.

Originality. It is proved that the filling of the channel of the heating network from the outside of the building with a layer of clay to a depth of $1 \mathrm{~m}$ and its sealing, sealing the introduction of heat and water supply networks through the foundation of the building and concreting the pit, reduce the volume activity of the radon in the room in 5-6 times.

Practical value. The current rare experience in increasing the radiation and social protection of the population of the city of Zhovti Vody, which lives in the zone of influence of uranium industry objects.

Key words: radioecology, uranium production, state programs, nature protection measures, radiation and social protection, population.

Рекомендована к публикации д. т. н. А. О. Гуриным Поступила 27.09.2018 